\title{
Pengembangan dan Perkembangan Pemikiran Hukum Pertanian di Indonesia
}

\author{
Tristam Pascal Moeliono ${ }^{\star}$, Koerniatmanto Soetoprawiro ${ }^{\star \star}$ \\ Fakultas Hukum Universitas Parahyangan \\ *tristam@unpar.ac.id

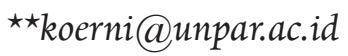

\begin{abstract}
Agricultural law is an emerging specialized field in Indonesian legal discourse and the public as well as academics has yet to get acquainted with this new perspective. The importance of agricultural law should be placed in relation with the fact that the Indonesian government, even after more then 75 year of independence, did not seriously address the plight of peasants and fishermen, living in rural areas throughout Indonesia. Agricultural law as a perspective is developed to bring back the focus of national development to agriculture in its widest sense. The focus of analysis of this approach will be on policies and rules regarding agriculture and how it affects peasantsfarmers working in informal-semi formal setting as well those working in the agroindustry and business. Other basic concepts employed relates to ecological-social justice, food sovereignty, security, and safety. Hopefully, this new approach to human development and agriculture may contribute to a better analysis of the plight of agriculture in Indonesia and how to improve this particular sector.
\end{abstract}

Keywords: agricultural law; food security, sovereignty, and safety; poverty; social inequity. 


\begin{abstract}
Abstrak
Hukum pertanian sebagai suatu kajian belum begitu dikenal dalam khasanah ilmu hukum Indonesia. Masyarakat umum, akademisi dan praktisi hukum masih harus berkenalan dengan pendekatan ini. Pentignya hukum pertanian harus ditempatkan dalam konteks kurangnya kepedulian rezim pemerintah Indonesia, bahkan dalam kurun waktu 75 tahun sejak merdeka, pada pembangunan sektor pertanian rakyat. Hukum pertanian merupakan satu upaya untuk mendorong kehidupan pertanian di Indonesia dan mayoritas masyarakat petani (bukan semata-mata perkebunan besar) menjadi bagian dari kehidupan modern yang manusiawi. Fokus kajian hukum pertanian adalah kebijakan dan aturan hukum yang diterbitkan pemerintah dari waktu ke waktu di bidang pertanian dalam arti luas yang bersentuhan dengan kehidupan petani-nelayan, mereka yang bekerja di sektor-sektor informal maupun semi formal sampai dengan agrobisnis dan industri. Sebagai titik tolak, digunakan konsep-konsep dasar keadilan sosial-ekologi, ketahanan-kedaulatan dan keamanan pangan. Salah satu sumbangan yang diharapkan adalah munculnya perspektif pemikiran dan solusi konstruksif yang baru untuk membangun manusia serta agrikultur dalam rangka menangani persoalan kemiskinan dan ketidakadilan sosial di Indonesia.
\end{abstract}

Kata kunci: hukum pertanian; kedaulatan, ketahanan, dan keamanan pangan; kemiskinan; ketidakadilan sosial.

\title{
A. Pendahuluan
}

Artikel ini membahas suatu cabang atau bidang hukum yang relatif belum banyak digarap dalam diskursus hukum di Indonesia: hukum pertanian. Sebagai negara agraris dan penduduknya yang mayoritas petani, ${ }^{1}$ Indonesia sebenarnya berkepentingan untuk secara serius mengembangkan hukum pertanian. Adanya perhatian dan pengembangan hukum pertanian yang lebih serius tentu akan

1 Menurut data Badan Pusat Statistik, jumlah petani di Indonesia pada 2018 adalah 33.487.806 orang. Badan Pusat Statistik Republik Indonesia, Hasil Survei Pertanian Antar Sensus (SUTAS) 2018 (Jakarta: Badan Pusat Statistik, 2018), hlm. 24. Publikasi ini tersedia di https://www.bps.go.id/publicatio $\mathrm{n} / 2019 / 10 / 31$ / 9567dfb39bd984aa45124b40/hasil-survei-pertanian-antarsensus--sutas--2018-seri-a2.html. 
berkorelasi luas pada kebutuhan dan hajat seluruh umat manusia, lebih-lebih bagi mereka yang menggantungkan hidupnya pada sektor tersebut. Sebagai bagian dari ikhtiar untuk turut mengembangkannya, artikel ini akan mendiskusikan mengapa pengembangan hukum pertanian diperlukan, bagaimana ruang lingkup garapannya, dan apa pula relevansinya.

Pembahasan tentang pengembangan dan perkembangan hukum pertanian menjadi relevan saat ini dengan situasi yang tengah berlangsung sejak awal tahun ini, ialah pandemi covid 19, beserta segala dampak sosial ekonominya. Sebelum pecah prahara covid 19, Indonesia diberitakan telah mengalami kenaikan kelas: dari Negara Berkembang (Developing Country) menjadi Negara Maju (Developed Country). ${ }^{2}$ Kemudian pangeblug datang pada awal 2020 dan pertumbuhan ekonomi nasional yang dibanggakan dengan cepat berkontraksi. ${ }^{3}$ Diyakini pula akan butuh waktu lama sebelum ekonomi nasional Indonesia dapat kembali menunjukkan pertumbuhan positif. Hal yang sama, namun demikian, dialami pula oleh negaranegara lain di seluruh dunia, tidak terkecuali raksasa ekonomi dunia seperti Tiongkok, Amerika Serikat, Jepang, Korea Selatan maupun negara-negara Uni Eropa. Kombinasi dari krisis di tingkat global dan nasional ini sekaligus mengancam keberlanjutan global chain production ${ }^{4}$ termasuk di bidang pertanian-peternakan. Singkat kata,

2 Tempo.Co, "US Removes Indonesia from Developing Countries List", https: / / en.tempo.co/ read/1311451/us-removes-indonesia-fromdeveloping-countries-list, 24/02/2020, diakses 10/09/2020. Sebaliknya, banyak yang meragukan dan membantah kepantasan penggolongan Indonesia sebagai negara maju. Misal: Detik.Com, "Ini Berbagai Alasan Indonesia Belum Pantas Disebut Negara Maju” https: / / finance.detik.com/ berita-ekonomi-bisnis / d-4917366/ini-berbagai-alasan-indonesia-belumpantas-disebut-negara-maju, 27/02/2020, diakses 10/09/2020.

3 Ginandjar Kartasasmita, "Pandemi dan Beban Utang”, Kompas, 11/ 09/2020: 6.

4 Global value chain: The full range of activities (design, production, marketing, distribution and support to the final consumer, etc) that are divided among multiple firms and workers across geographic spaces to bring a product from its conception to its end use and beyond. Periksa: United Nations Industrial Development Organization, "What are Global Value Chains and Why Do They Matter?”, https://iap.unido.org/articles/what- 
ekspor-impor bahan-bahan pangan (mentah ataupun jadi) dari dan menuju Indonesia dari seluruh belahan dunia terganggu.

Dampak sosial ekonomi dari itu semua akan terasa di tingkat akar rumput di mana pun juga. Indonesia sebelum krisis sudah berhadapan dengan bencana-bencana ekologis dan sejak Januari 2020 sampai dengan entah kapan akan terus berhadapan dengan tidak saja krisis kesehatan namun juga ekonomi-politik. ${ }^{5}$ Berhadapan dengan krisis kesehatan masyarakat sekaligus ekonomi nasional (dan global), satu persoalan akut lain yang dihadapi pemerintahan negara mana pun, termasuk Indonesia adalah bagaimana menjaga pasokan dan ketersediaan pangan secara berlanjut bukan hanya di Ibukota Jakarta atau pulau Jawa dengan jumlah penduduk terpadat di Indonesia, namun di seluruh wilayah Negara.

Ketersediaan pangan bagi seluruh penduduk baik di masa normal apalagi di masa krisis seperti sekarang sudah jelas adalah urusan menjaga kepentingan umum (negara) dan tidak bisa diserahkan begitu saja pada rumah tangga apalagi individu. Dalam situasi normal, sebelum ada pandemi, di Indonesia sudah teramati adanya gejala gizi buruk, wasting dan stunting (gangguan tumbuh kembang pada anak karena kurangnya asupan protein $)^{6}$ dan musibah

are-global-value-chains-and-why-do-they-matter, diakses 12/09/2020.

5 Sebagai gambaran, Badan Nasional Penanggulangan Bencana (BNPB) melaporkan, lebih dari 1.300 bencana terjadi sejak Januari hingga akhir Mei 2020 (https:/ / bnpb.go.id/berita/lebih-dari-1-300-bencana-hingga-akhirmei-2020, "Lebih dari 1.300 Bencana Hingga Akhir Mei 2020”, 1/6/2020, diakses 16/11/2020. Terkait pandemi Covid 19, yang pada prinsipnya juga merupakan bencana lingkungan, berdampak buruk pada pertumbuhan ekonomi internasional maupun nasional. Baca: OECD, "Building Confidence Amid an Uncertain Recovery”, OECD Economic Outlook, Interim Report September 2020, http: / / www.oecd.org/ economic-outlook/, diakses 16/11/2020. Disebutkan bahwa: All G20 countries with the exception of China will have suffered recession in 2020. Although a fragile recovery is expected next year, in many countries output at the end of 2021 will still be below levels at the end of 2019, and well below what was projected prior to the pandemic.

6 Baca, antara lain, UNICEF, "Laporan Status Anak Dunia 2019: Anak, Pangan, dan Gizi”, https://www.unicef.org/indonesia/id/status-anakdunia-2019, diakses 12/09/2020. 
kelaparan di Papua. ${ }^{7}$ Keduanya mengindikasikan ada persoalan besar yang harus ditangani pemerintah berkenaan dengan penyediaan dan pengadaan pangan di Indonesia. Bersamaan dengan itu perlu dicermati gangguan lain terhadap penyediaan dan pengadaan pangan pada skala nasional, yakni konversi lahan hutan dan sawah dalam skala masif dan bencana ekologi yang terkait dengannya baik dalam skala kecil maupun besar. ${ }^{8}$ Tidak boleh pula dilupakan di sini fenomena kegiatan perikanan yang tidak sah, tidak diatur, dan tidak dilaporkan (illegal unregulated and unreported fishing, IUU) di seluruh wilayah tangkapan ikan Indonesia. ${ }^{9}$ Sulitnya memberantas IUU jelas berdampak terhadap pemiskinan nelayan-nelayan tradisional yang tersebar di seluruh nusantara.

Berhadapan dengan krisis multidimensional tersebut, pertanyaan besar yang muncul adalah apa sumbangan dari ilmu hukum di Indonesia? Salah satu dari sekian banyak pemikiran ditawarkan melalui pengembangan kajian hukum pertanian. Tulisan ini memperkenalkan kajian hukum pertanian sebagai satu pendekatan baru, satu sumbangan pemikiran baru dalam khasanah ilmu hukum Indonesia, yang menempatkan usaha pertanian dalam arti luas. Satu

7 BBC Indonesia, “Kelaparan' dan Wabah Campak di Papua Menyebar, Korban Jiwa Hampir 100 Orang”, 22/01/2018, https://www.bbc.com/ indonesia/majalah-42758636, diakses 12/09/2020; BBC Indonesia, "Covid19 Papua: 'Rawan Kelaparan' Saat Pandemi, Warga 'Berkebun Massal’”, 22/05/2020, https://www.bbc.com/indonesia/indonesia-52661830, diakses 12/09/2020.

8 Baca, antara lain: Anny Mulyani, Dwi Kuncoro, Dedi Nursyamsi, dan Fahmuddin Agus, "Analisis Konversi Lahan Sawah: Penggunaan Data Spasial Resolusi Tinggi Memperlihatkan Laju Konversi yang Mengkhawatirkan”, Jurnal Tanah dan Iklim, 40, 2 (2016): 121-133; Erni Purbiyanti, Muhammad Yazid, dan Indri Januarti, "Konversi Lahan Sawah di Indonesia dan Pengaruhnya terhadap Kebijakan Harga Pembelian Pemerintah (HPP) Gabah/Beras”, Jurnal Manajemen \& Agribisnis, 14, 3 (2017): 209-217.

9 Periksa: http:/ / iuufishingindex.net/profile/indonesia, diakses 15/10/2020. Di dalamnya dapat ditemukan overall score kerentanan Indonesia terhadap IUU. Untuk upaya Indonesia melawan IUU, periksa: Basten Gokkon, "Everything’s Moving': Indonesia Seeks Global Pushback on Illegal Fishing”, https://news.mongabay.com/2019/01/everythings-movingindonesia-seeks-global-pushback-on-illegal-fishing/, 06/01/2019, diakses $15 / 10 / 2020$. 
hal yang dicermati adalah minimnya perhatian kajian hukum negara pada persoalan pertanian (agrikultur) dalam arti luas. Betul bahwa Undang-Undang Pokok Agraria (UU Nomor 5 Tahun 1960) berupaya menjadi landasan hukum bagi pengembangan kebijakan pengelolaan agraria yang dipahami sebagai sumber daya alam dalam arti luas. ${ }^{10}$ Namun dalam perkembangannya, perhatian pemerintah, khususnya pada masa Orde Baru, diberikan pada pengelolaan sumber daya alam secara sektoral: hukum kehutanan, hukum pertambangan, dan hukum migas. ${ }^{11}$ Salah satu faktor minimnya perhatian pemerintah pada pertanian adalah faktor warisan kebijakan pembangunan. Perhatian pemerintah kolonial Belanda pada agraria lebih pada eksploitasi (petani kecil: culturstelsel) dan baru kemudian pada pengembangan perkebunan besar. Tidak ada urusan dan kepentingan Belanda di perdesaan dan pertanian ini, begitu juga pada nasib petani dan pertanian rakyat. Sayangnya kecenderungan ini pun ternyata terus berlanjut pasca kolonialisme. Itu sebabnya, terlepas dari semangat Orde Baru untuk mengatur dan mengendalikan kehidupan masyarakat desa, ${ }^{12}$

10 Pasal 14 Undang-Undang Pokok Agraria (No. 5 tahun 1960): "perencanaan pemanfataan sumber daya alam dilakukan untuk keperluan negara, peribadatan, pusat kehidupan sosial budaya dan kesejahteraan masyarakat, pengembangan produksi pertanian, peternakan, perikanan serta pengembangan industri, transmigrasi, dan pertambangan”. Sementara itu, berkaitan dengan kelestarian pengelolaan sumber daya alam, Pasal 14: "memelihara tanah, termasuk menambah kesuburannya serta mencegah kerusakannya adalah kewajiban tiap-tiap orang, badan hukum, atau instansi yang mempunyai hubungan hukum dengan tanah itu, dengan memperhatikan pihak yang ekonominya lemah".

11 Hukum Migas: Undang-undang Nomor 44 Prp. Tahun 1960 tentang Pertambangan Minyak dan Gas Bumi, Undang-undang Nomor 15 Tahun 1962 tentang Penetapan Peraturan Pemerintah Pengganti Undang-undang Nomor 2 Tahun 1962 tentang Kewajiban Perusahaan Minyak Memenuhi Kebutuhan Dalam Negeri, dan Undang-undang Nomor 8 Tahun 1971 tentang Perusahaan Pertambangan Minyak dan Gas Bumi Negara (diganti dengan Undang-undang Nomor 22 Tahun 2001); Hukum Kehutanan: Undang Undang Nomor 5 Tahun 1967 tentang Ketentuan-ketentuan Pokok Kehutanan (diganti dengan Undang-undang Nomor 41 Tahun 1999 jo. Undang-undang Nomor 19 Tahun 2004); Hukum Pertambangan: Undangundang Nomor 11 Tahun 1967 tentang Ketentuan Pokok Pertambangan (diganti Undang-undang Minerba Nomor 3 Tahun 2020).

12 Hans Antlov, Negara dalam Desa: Patronase Kepemimpinan Lokal (Jakarta: 
tidak ada cabang hukum pertanian dalam struktur hukum nasional Indonesia, meskipun mayoritas masyarakat warga Indonesia adalah petani. Dengan kata lain, tidak ada pengaturan dan perlindungan hukum secara komprehensif atas kehidupan perdesaan dan pertanian tersebut. ${ }^{13}$

Dalam arti luas, pertanian (agriculture) bukan sekadar bercocok tanam skala usaha perorangan, namun juga termasuk industrialisasi agrikultur sebagai satu cara memerangi dan menanggulangi kemiskinan. ${ }^{14}$ Namun demikian, titik tolaknya bukanlah pendekatan karitatif dalam hukum sosial atau sekadar upaya memerangi kemiskinan. Sebaliknya, gagasan besarnya justru beranjak dari pemikiran tentang keadilan sosial dan ekologi, menelaah dari sudut pandang hukum persoalan-persoalan kedaulatan, ketahanan, dan keamanan pangan di mana justru peran sentral ada pada petani-nelayan yang bekerja pada sektor informal dan justru menjadi tumpuan ekonomi, terutama ketika terjadi krisis ekonomi global.

Untuk tujuan memperkenalkan perspektif hukum pertanian dalam kerangka di atas, artikel ini setelah ini akan menelaah situasi dan kondisi empiris pertanian Indonesia dalam kaitan dengan kebijakan pembangunan yang dicanangkan pemerintah. Setelahnya akan ditelaah konsep-konsep keadilan sosial-ekologi dalam kaitan dengan kedaulatan-ketahanan dan keamanan pangan yang melandasi gagasan pengembangan hukum pertanian. Pada bagian berikutnya akan diulas definisi dan cakupan hukum pertanian dan sumbangannya bagi khasanah ilmu hukum Indonesia. Pada bagian akhir, yaitu kesimpulan, akan diberikan rangkuman dan sejumlah rekomendasi

Lappera Pustaka Utama, 2013).

13 Hal ini sebagaimana dikemukakan Koerniatmanto Soetoprawiro dalam tiga bukunya terkait hukum pertanian, yaitu Pengantar Hukum Pertanian (Jakarta: Gapperindo, 2013); Hukum Agribisnis dan Agroindustri: Pengaturan dan Perlindungan Hukum atas Proses Agribisnis dan Agroindustri (Bandung, Unpar Press, 2016); Hukum Akuabisnis dan Akuaindustri (Bandung: UnparPress, 2020).

14 Pengertian pertanian dalam arti luas ini digunakan dan dikembangkan oleh Sjamsoe'oed Sadjad, Benih, Pertanian dan Kehidupan: Olah Pikir Sjamsoe'oed Sadjad, https: / / drive.google.com/file/d/1wdBPi1cfoT2Mius2GUuoi0Ayp ENjsDBL/view, diakses 19/10/2020. 
arah studi lanjut.

\section{B. Hukum (Ekonomi-Pembangunan) dan Ketidakadilan Sosial-Ekologi}

Sejak awal kemerdekaan, terutama pada awal mula pemerintah Indonesia mulai dapat menata diri, selepas pengakuan kedaulatan oleh Belanda (1949) telah dicanangkan pentingnya pembangunan bangsa-negara. Presiden Soekarno menegaskan pentingnya bangsa ini membangun dengan berdiri di atas kaki sendiri. Dalam pidato kenegaraan Bung Karno pada 17 Agustus 1959, yang diberi judul "Penemuan Kembali Revolusi Kita,"15 dinyatakan Indonesia akan membangun negeri dengan kekuatan modal sendiri secara berencana, dan terpimpin oleh negara. Modal sendiri merupakan modal nasional yang bersifat progresif; sedangkan modal luar negeri dijadikan pelengkap dengan syarat tidak mengikat. Haluan negara pertama ini dikenal sebagai Manifesto Politik (Manipol) yang berintikan lima unsur, yakni UUD 1945, Sosialisme Indonesia, Demokrasi Terpimpin, Ekonomi Terpimpin, dan Kepribadian Indonesia. Kelima unsur itu biasa disebut USDEK. Amanat Presiden tersebut disampaikan pada Dewan Perancang Nasional (Depernas; sekarang Badan Perencanaan Pembangunan Nasional) secara tertulis pada 28 Agustus 1959 untuk dikembangkan menjadi pola Pembangunan Nasional Semesta Berencana (PNSB). ${ }^{16}$

Dengan berpindahnya kekuasaan penyelenggaraan Negara ke tangan Jenderal TNI Soeharto pada 1967-68, gagasan perlunya pembangunan state centered and top down dengan modal utama sumberdaya alam Indonesia yang (masih) berlimpah tidak serta

15 Teks lengkap tersedia di https: / / marnette.home.xs4all.nl/scans / overheid/ kembali.pdf, diakses 15/10/2020.

16 Periksa: Ketetapan Majelis Permusyawaratan Rakyat Sementara Republik Indonesia Nomor II/MPRS/1960 tentang Garis-garis Besar Pola Pembangunan Nasional Semesta Berencana Tahapan Pertama 1961-1969. Perhatikan pula fakta bahwa Presiden Soekarno tidak mutlak anti investasi. Bahkan ia menerbitkan Peraturan Presiden Nomor 21 Tahun 1961 tentang Penetapan Prioritas dan Prosedur Kredit Luar Negeri dalam Hubungan Pelaksanaan Proyek-proyek Pembangunan Nasional Semesta Berencana. 
merta dibuang. ${ }^{17}$ Satu hal yang justru berbeda adalah sikap terhadap modal asing. Pemerintahan Orde Baru untuk memuluskan masuknya investasi asing menerbitkan UU Nomor 1 Tahun 1967 tentang Penanaman Modal Asing. Diakui dalam butir a konsideran UU ini, "bahwa kekuatan ekonomi potensil yang dengan karunia Tuhan yang Maha Esa terdapat banyak di seluruh wilayah tanah air yang belum diolah untuk dijadikan kekuatan ekonomi riil, yang antara lain disebabkan oleh karena ketiadaan modal, pengalaman dan tekhnologi". Karena itu, dalam butir f disebutkan, "bahwa penggunaan modal asing perlu dimanfaatkan secara maksimal untuk mempercepatpembangunan ekonomi Indonesia serta digunakan dalam bidang-bidang dan sektor-sektorg yang dalam waktu dekat belum dan atau tidak dapat dilaksanakan oleh modal Indonesia sendiri”.

Ditengarai dengan ini, terjadi perubahan pilihan ideologis antara ekonomi sosialis yang beralih ke sistem ekonomi (neo-) liberal kapitalis. Terlepas dari itu, disebutkan bahwa pola pembangunan yang dicanangkan Orde Baru (jangka pendek-menengah dan panjang) berhasil mengoptimalkan eksploitasi sumberdaya alam (mineralmigas-kehutanan).

Pada saatsama, sisilain dari keberhasilan kebijakan pembangunan top down yang diancangkan pemerintahaan Orde Baru (1967-1997) adalah fakta tidak meratanya penikmatan hasil pertumbuhan ekonomi dan bertambah cepatnya peningkatan kesenjangan kaya-miskin di kota-kota besar di Indonesia maupun secara umum seluruh wilayah Indonesia. Terutama Jakarta menjadi pusat kegiatan pertumbuhan ekonomi dan pada saat sama, dengan meningkatnya urbanisasi, muncul dan terjadi pemiskinan rakyat di daerah (termasuk pedesaan) di seluruh wilayah Indonesia. Bahkan kesenjangan ekonomi dengan segala permasalahan sosial yang terkait dengannya muncul pula di kawasan perkotaan, terutama yang menjadi pusat pertumbuhan ekonomi nasional, dalam wujud kantong-kantong pemukiman

17 Ketetapan Majelis Permusyawaratan Rakyat Sementara Republik Indonesia Nomor XXIII/MPRS / 1966 tentang Pembaharuan Kebijaksanaan Landasan Ekonomi, Keuangan dan Pembangunan. 
kumuh di bantaran sungai atau pinggiran dan sekitar tempat-tempat pembuangan sampah. ${ }^{18}$

Pada lain pihak, suatu kebutuhan tidak terbatas untuk secara berlanjut mengeksploitasi sumber daya alam untuk memenuhi kebutuhan dasar termasuk yang subsider dan tersier juga kian terus bertambah dan tidak pernah terpuaskan. Persoalan ini sebenarnya sudah dibincangkan sejak 1967 (Rachel Carson; the Silent Spring) ${ }^{19}$ dan 1970 (Our Common Future). ${ }^{20}$ Pesan tentang keterbatasan daya dukung bumi yang disampaikan penulis-penulis asing itu kemudian memunculkan pengembangan gagasan pembangunan berkelanjutan yang berwawasan lingkungan di tingkat dunia ${ }^{21}$ dan juga di Indonesia. Gagasan itu pun melahirkan di Indonesia kajian hukum tata lingkungan (Munadjat Danusapuro) ${ }^{22}$ dan hukum lingkungan (Koesnadi Hardjasoemantri) ${ }^{23}$ di awal 1980an. Secara sederhana di sini hukum lingkungan dimengerti sebagai hukum yang mengatur tatanan lingkungan (lingkungan hidup) ataupun menyangkut penetapan nilai-nilai yang sedang berlaku dan nilai-nilai yang diharapkan diberlakukan di masa mendatang. ${ }^{24}$ Pandangan-

18 Baca pula: Mike Davis, Planet of Slums (London \& Newyork: Verso, 2006).

19 Rachel Carson, “The Silent Spring”, https://ejcj.orfaleacenter.ucsb.edu/ wp-content / uploads / 2017 / 06 / 1962.-Rachel-Carson-Silent-Spring.pdf, diakses $12 / 09 / 2020$.

20 United Nations, "Report of the World Commission on Environment and Development: Our Common Future”, https://sustainabledevelopment. un.org/content/documents/5987our-common-future.pdf, diakses $12 / 09 / 2020$.

21 Dalam Agenda 21, dicanangkan tentang rencana tindakan komprehensif yang akan diambil secara global, nasional, dan lokal untuk mencapai pembangunan berkelanjutan yang berwawasan lingkungan. https:// sustainabledevelopment.un.org/outcomedocuments/agenda21, "Agenda 21, Unced 1992", diakses 15/10/2020.

22 St. Munadjat Danusaputro, Hukum Lingkungan; Buku I (Jakarta: Binacipta, 1985).

23 Koesnadi Hardjasoemantri, Hukum Tata Lingkungan (Yogyakarta: Gadjah Mada University Press, 1983).

24 Hukum lingkungan itu berkenaan dengan kebijaksanaan lingkungan yang ditetapkan penguasa yang berwenang di bidang pengelolaan lingkungan. Siti Sundari Rangkuti, Hukum Lingkungan \& Kebijaksanaan Lingkungan Nasional (Surabaya: Airlangga University Press, edisi keempat, 2020), hlm. 5 . 
pandangan yang dikembangkan kemudian mendorong pemerintah untuk mendirikan Kementerian Lingkungan Hidup, Badan Pengendalian Dampak Lingkungan Hidup, dan berbagai instrumen hukum untuk mendorong dan mengendalikan pembangunan di Indonesia. Namun apakah ini semua sudah cukup?

Dari sudut pandang lain dapat dikatakan pula bahwa pertumbuhan ekonomi yang dikejar pemerintahan Orde Baru (dan rezim setelahnya) dengan bantuan modal, terutama asing, justru memunculkan persoalan ketidakadilan sosial dan ekologi. Di sini keadilan sosial dipahami dalam konteks keadilan distributif; kesempatan yang sama untuk menikmati hasil pembangunan atau pertumbuhan ekonomi. ${ }^{25}$ Berkaitan dengan itu persoalan keadilan sosial terkait dengan jaminan penguasaan sumberdaya (access to resources, termasuk ke dalamnya benih), equity (tidak dapat dipersamakan dengan equality), pengakuan akan keberagaman (diversity), peran serta (public participation) dan pengakuanpenghormatan-perlindungan atas hak asasi manusia (human rights). ${ }^{26}$

Sedangkan keadilan ekologi dapat dimaknai sebagai “... as the fair treatment and meaningful involvement of all people regardless of race, color, national origin, or income with respect to the development, implementation, and enforcement of environmental laws, regulations, and policies" ${ }^{27}$ Di sini, keadilan ekologi berarti adanya peran serta dan pelibatan masyarakat tanpa memandang sukuras-agama dalam penetapan kebijakan-kebijakan pembangunan yang secara nyata berdampak pada kehidupan sosial-ekonomi mereka.

Berkaitan dengan itu, ketidakadilan ekologi yang nyata muncul dalam ragam bencana, termasuk kemiskinan-pemiskinan serta

25 United Nations, Social Justice in an Open World: The Role of the United Nations (New York: United Nations Publication, 2006), https: / /www.un.org/esa/ socdev/documents/ifsd/SocialJustice.pdf. Sebaliknya, ketidakadilan sosial dikaitkan pula dengan kesenjangan (inequity) dalam penikmatan hasil-hasil pembangunan.

26 The Five Principles of Social Justice, tersedia di https://onlinedegrees. kent.edu/political-science/ master-of-public-administration/community/ five-principles-of-social-justice, diakses 15/10/2020.

27 International Encyclopedia of the Social \& Behavioral Sciences, 2001. 
kelaparan di berbagai belahan dunia, dalam pandangan Vandana Shiva diakibatkan oleh cara kita sebagai manusia, masyarakat dan negara memandang lingkungan. Ia menyatakan, ${ }^{28}$

I believe that every wrong action with respect to the land is a wrong action with respect to biodiversity, is a wrong action that leads to consequences for our health, is a wrong action that creates conflicts and the end of peace, and is a wrong action that leads to more emissions. Land degradation, biodiversity, erosion, public health, women's situations, climate change, are not separate. They are just different facets of the same process, which is an indifference to the ecological processes of the Earth, and living at war with the Earth.

Apa yang pada intinya dinyatakan di atas adalah, manusia sebagai bagian dari lingkungan justru menyatakan perang melawan alam yang kemudian menghasilkan degradasi bumi, kehancuran keanekaragaman hayati, perubahan iklim, dan lain-lain. Sebab itu pula, sebagai respons dari ancaman kehancuran alam ini, keadilan ekologis dikembangkan sebagai "idea of shared responsibility for livelihoods and environments or what we have termed common based governance. Typically, ecological justice positions social and ecological interest ahead of market liberalism or economic growth". ${ }^{29}$ Beranjak dari itu pula, maka, dari sudut pandang kebutuhan mewujudkan keadilan-sosial dan ekologi, terutama mereka yang terpinggirkan, korban pembangunan dalam bayangan Peter L. Berger, ${ }^{30}$ yang acapkali terabaikan oleh

28 Vandana Shiva, "Earth Democracy: Sustainability, Justice and Peace”, Buffalo Environmental Law Journal, 26, 1 (2019); Vandana Shiva, Earth Democracy: Sustainability, Justice and Peace (London: Zed Books Ltd., 2005).

29 John Byrne, Leigh Glover, dan Hugo F. Aloe, "Globalization \& Sustainable Development: A Political Ecology Strategy to Realize Ecological Justice”, dalam Global Development of Organic Agriculture: Challenges and Prospects, ed. Niels Halberg, Hugo Fjelsted Alroe, Marie Trydeman Knudsen, dan Erik Steen Kristensen (Wallingford: CABI Publishing, 2006).

30 Peter. L. Berger, Piramida Kurban Manusia: Etika Politik dan Perubahan Sosial, terj. A. Rahman Tolleng, (Jakarta: LP3ES, 1982). Melalui buku ini Berger mengajukan kritikan baik terhadap ideologi sosialis memaupun kapitalisme. Keduanya, dengan cara berbeda, menawarkan jalan menuju modernisasi dan kemakmuran, sekalipun persamaannya adalah sekaligus meminta korban-korban manusia untuk menyangga "pembangunan". Ia selanjutnya juga menegaskan pentingnya kebijakan pembangunan untuk dibangun di atas calculus of meanings (perhitungan makna) dan calculus of pains (perhitungan penderitaan). 
pemerintah, harus kembali menjadi pusat perhatian negara. Mengejar pertumbuhan ekonomi atau mewujudkan Indonesia sebagai negara yang siap lepas landas (mengejar ketertinggalan dari negara maju) melalui pengembangan hukum administrasi berkembang, antara lain, menjadi hukum ekonomi pembangunan, adalah satu hal. Persoalan lain yang akan terus membayang adalah bagaimana mengatasi baik kemiskinan maupun khususnya pemiskinan sebagai dampak pembangunan.

Selain itu, masih luput dari perhatian pemerintah maupun pakar-pakar hukum tersebut, satu persoalan teoretikal-praktikal yang sebenarnya erat berkelindan dengan kebijakan pengelolaan lingkungan hidup dalam arti seluas-luasnya: bagaimana pemerintah Indonesia seharusnya menjaga keberlangsungan bangsa berdasarkan pandangan kedaulatan pangan (food sovereignty) ${ }^{31}$ dan/atau ketahanan pangan (food security). ${ }^{32}$ Terkait berkelindan dengan itu adalah ihwal

31 Food sovereignty is the people, Countries', or State Unions' RIGHT to define their agricultural and food policy, without any dumping vis-ā-vis third countries. Food sovereignty includes: (a) prioritizing local agricultural production in order to feed the people, access of peasants and landless people to land, water, seeds, and credit. Hence the need for land reforms, for fighting against GMOs (Genetically Modified Organisms), for free access to seeds, and for safeguarding water as a public good to be sustainably distributed; (b) the right of farmers, peasants to produce food and the right of consumers to be able to decide what they consume, and how and by whom it is produced; (c) the right of Countries to protect themselves from too low priced agricultural and food imports. (d) agricultural prices linked to production costs : they can be achieved if the Countries or Unions of States are entitled to impose taxes on excessively cheap imports, if they commit themselves in favor of a sustainable farm production, and if they control production on the inner market so as to avoid structural surpluses; (d) the populations taking part in the agricultural policy choices; and (e) the recognition of women farmers' rights, who play a major role in agricultural production and in food. Periksa: La Via Campesina, "Food Sovereignty", https://viacampesina.org/en/food-sovereignty/, 15/01/2003, diakses 10/09/ 2020.

32 Food security exists when all people, at all times, have physical, social and economic access to sufficient, safe and nutritious food which meets their dietary needs and food preferences for an active and healthy life. Household food security is the application of this concept to the family level, with individuals within households as the focus of concern. Food insecurity exists when people do not have adequate physical, social, or economic access to 
keamanan pangan (food safety). ${ }^{33}$ Ketiga pendekatan ini (kedaulatan, ketahanan, dan keamanan pangan) serta merta bersentuhan dengan ketersediaan dan keberlanjutan pangan bagi semua. Pada gilirannya itu semua kembali berkait dengan upaya pencegahan dan pemberantasan kemiskinan melalui pemberdayaan (empowermentemancipation) para mayoritas petani kecil, termasuk masyarakat nelayan kecil di pesisir Indonesia yang jelas terbukti memiliki daya lenting lebih baik dari pada industri pertanian dan perkebunan besar serta jaminan pasokan, ketersediaan dan keterjangkauan pangan bagi semua orang. Pilihan lain yang juga mungkin dan penting adalah ikhtiar mempertautkan usaha-usaha agrikultur dalam skala kecil ini dengan kegiatan ekonomi modal besar.

Perdebatan serupa sebenarnya telah dibahas secara fragmentaris atau sektoral dalam kajian hukum agraria-pertanahan (masalah konflik pertanahan dan petani tidak bertanah) atau, seperti disinggung di atas, dalam kajian hukum lingkungan-tata ruang (laju konversi lahan pertanian demi pembangunan perkotaan-industri, konversi hutan demi perkebunan besar). Persoalan sama sekarang ini menjadi semakin genting dengan terus bertambahnya jumlah penduduk (Indonesia) di hadapan risiko bencana-bencana global. Bahkan dapat dikatakan, dengan atau tanpa pandemi (Covid 19) atau justru berhadapan dengan pandemi ini, keterjaminan pangan rakyat Indonesia, dalam konteks kedaulatan maupun ketahanan dan keamanan, tetap harus dijaga.

food as defined above. Periksa: FAO, “Trade Reforms and Food Security: Conceptualizing the Linkage, Commodity Policy and Projections Service Commodities and Trade Division", Food and Agriculture Organization of The United Nations Rome, 2003. Tersedia di http://www.fao.org/3/ y4671e/y4671e00.htm\#Contents.

33 Periksa Peraturan Pemerintah (PP) Nomor 86 Tahun 2019 (mencabut PP Nomor 28/2004 tentang Keamanan, Mutu dan Gizi Pangan), yang merumuskan keamanan pangan sebagai: kondisi dan upaya yang diperlukan untuk mencegah pangan dari kemungkinan cemaran biologis, kimia, dan benda lain yang dapat mengganggu, merugikan, dan membahayakan kesehatan manusia serta tidak bertentangan dengan agama, keyakinan, dan budaya masyarakat sehingga aman untuk dikonsumsi. 


\section{Hukum Pertanian: Ikhtiar Mengembangkan Paradigma Baru}

Pertanyaan pokok yang perlu dijawab adalah bagaimana peran dan tanggung jawab negara dalam pengadaan, penyebaran, dan pengaturan pasar berkaitan dengan pangan dalam arti luas termasuk ke dalam salah satu dari sembilan bahan pokok. ${ }^{34}$ Dalam kajian hukum ekonomi (nasional-internasional), ${ }^{35}$ hal ini diulas dalam kaitan dengan pilihan sistem ekonomi yang mendasari kegiatan pembangunan.

Selama 30 tahun lebih, pemerintah Indonesia di bawah rezim Orde Baru memilih dan menerapkan sistem ekonomi sosialis dengan nuansa neo-liberalisme dalam sistem politik patronase-otoritarian. Negara cq. Pemerintah menjadi motor dan penggerak sistem ekonomi nasional, misal dalam wujud rangkaian Ketetapan Majelis Permusyawaratan Rakyat (TAP MPR) tentang Garis-garis Besar Haluan Negara (GBHN) sampai dengan Rencana Pembangunan Jangka Panjang-Menengah dan Lima Tahunan. Salah satu sektor pembangunan yang dipersiapkan dalam rangka lepas landas menjadi negara industri maju adalah pengembangan peraturan, kebijakan, serta target-target capaian di bidang urusan pangan (pertanian, perkebunan, peternakan, kehutanan, bahkan seluruh pengelolaan sumber daya alam) atas nama pembangunan. Di masa itu pula, peran pemeritah (antara lain melalui Bulog) sangat besar dalam mengelola ketersediaan dan keamanan pasokan pangan. Di bidang pertanian atau tepatnya bidang pengadaan beras (salah satu dari sembilan bahan pokok), Presiden Soeharto pada 1984 membanggakan diri telah berhasil mengukir prestasi swasembada pangan. ${ }^{36}$ Sebagai

34 Keputusan Menteri Perindustrian dan Perdagangan Nomor 115/MPP/ Kep/2/1998, tanggal 27 Februari 1998.

35 Pendekatan yang pada era 1980’ diperkenalkan oleh Soenaryati Hartono dari Fakultas Hukum Universitas Padjadjaran, sebagaimana tersua dalam bukunya Hukum Ekonomi Pembangunan (Jakarta: BPHN dan Binacipta, 1982).

36 Iswara N. Raditya, "Swasembada Beras ala Soeharto: Rapuh dan Cuma Fatamorgana”, https://tirto.id/swasembada-beras-ala-soeharto-rapuhdan-cuma-fatamorgana-c2eV, 25 / 09/2018, diakses 10/ 09/2020. Dilaporkan: "Tampak begitu perkasanya ketahanan pangan Indonesia kala itu. Menurut 
bandingan, ikhtiar serupa pada era 80-90; dukungan pemerintah pada pendirian Badan Penyangga dan Pemasaran Cengkeh (BPPT), justru berakibat hancurnya pasar cengkeh dan pemiskinan petani. ${ }^{37}$

Pasca Orde Baru, kebijakan berubah dan dengan kehancuran negara-negara sosialis-komunis, semua negara dengan terpaksa atau diam-diam mengadopsi sistem ekonomi neo-liberal kapitalis, di mana negara berperan hanya sebagai pengawas-pengarah (steering but not rowing), ${ }^{38}$ dan penggerak roda ekonomi adalah swasta (modal asing dan dalam negeri), termasuk, dan ini perlu disebut dengan ragu, usaha menengah-kecil dan mikro ataupun juga sektor informal. Globalisasi ekonomi-politik ini sekaligus menegaskan inter-dependency sekaligus kerentanan negara dan masyarakat negara satu sama lain. Kedaulatan negara tidak lagi dapat dipahami sebagai kebebasan mutlak mengatur urusan dalam negeri, namun kebebasan yang niscaya peduli pada kepentingan masyarakat di tempat-tempat lain, bahkan generasi yang mendatang (inter \& intra generational equity). ${ }^{39}$ Dalam perkembangan selanjutnya justru kerentanan ini

Eduard Saoma, Direktur Jenderal FAO, Soeharto berjasa dalam menyusun kebijakan sehingga Indonesia berhasil mencapai swasembada pada 1984 dan menjaga stabilitas ketahanan pangan, setidaknya hingga 1986 ketika Saoma berkunjung ke Jakarta. Keberhasilan sama juga diklaim pemerintahan Presiden Joko Widod. Periksa: Kompas.Com, "Berhasil Swasembada Beras, Sejarah Baru pada Kepemimpinan Jokowi-JK, https: / / money.kompas.com/ $\mathrm{read} / 2019 / 10 / 01 / 072600226 /$ berhasil-swasembada-beras-sejarah-barupada-kepemimpinan-jokowi-jk?page=all, 01/10/2019, diakses 10/09/2020.

37 Petrik Matanasi, "Keculasan Orde Baru Membuat Harga Cengkeh Hancur”, https:/ / tirto.id/keculasan-orde-baru-membuat-harga-cengkehhancur-dhpR, 21/02/2019, diakses 19/10/2020; Tempo.Co, "Siapa Mau Bakar Cengkeh, Laporan Khusus”, https://majalah.tempo.co/read/ laporan-khusus/10204/siapa-mau-bakar-cengkeh, 07/03/1992, diakses $19 / 10 / 2020$.

38 Baca lebih lanjut: David Osborne dan Ted Gaebler, Reinventing Government: How the Entrepreneurial Spirit Transforming the Public Sector (Newyork: Addison-Wesley, 1992); B. Guy Peters, "Steering, Rowing, Drifting, or Sinking? Changing Patterns of Governance”, Urban Research \& Practice, 4, 1 (2011): 5-12.

39 Due to the existence of entropy, exhaustible resources, and resource scarcity, the condition of sustainability as currently conceived seems unlikely ever to be achieved. Nevertheless, Humankind can ensure advancement towards ecologically sustainable development, thereby prolonging the 
memunculkan reaksi balik berupa tuntutan dan kehendak untuk kembali menetapkan negara sebagai penentu dan penggerak roda ekonomi nasional (rowing and steering). ${ }^{40}$

Di dalam dan berhadapan dengan sistem ekonomi neo-liberalkapitalis ini, seperti telah diindikasikan di atas, persoalan keadilan sosial dan ekologi-lingkungan (social \& ecological-environmental justice) menjadi sangat penting. Bagi mayoritas masyarakat Indonesia yang tinggal di pedesaan ataupun terpaksa hijrah ke perkotaan dan mengisi relung-relung sektor informal dan hidup berkerumun di pemukiman informal-kampung-kota, persoalan keadilan sosial dan ekologi bukanlah persoalan teoretik tentang salah satu sila Pancasila atau bagaimana menafsir Pasal 33 (3) UUD 1945, melainkan soal bagaimana memperjuangkan hidup yang bermartabat.

Persoalan sama dari sudut pandang berbeda memunculkan pertanyaan: seberapa jauh sebenarnya negara cq. pemerintah peduli pada pengembangan pertanian rakyat (kecil-informal, bukan dalam skala industri-perkebunan besar), nelayan tradisional (bukan industri perikanan), dan mayoritas rakyat (kecil) di Indonesia yang bekerja di sektor informal? Ketika berbicara tentang pembangunan dan pemajuan ekonomi nasional, di mana, dalam istilah Presiden Soekarno, kaum marhaen ini ditempatkan? Dalam pada itu perlu dicamkan pula fakta sekitar 97 persen lapangan kerja di Indonesia disumbangkan oleh sektor UMKM, 50 persen di antaranya di bidang pertanian, peternakan dan perikanan. UMKM di bidang pertanian menyumbang sekitar 48 persen dari angkatatan kerja di Indonesia. Sementara itu, justru mereka yang berada di pedesaan (agrarisnelayan tradisional) justru mengalami dan lebih rentan terhadap

existence of social and ecological stability, by encouraging the proposed inter-generational and intra generational equity requirements. Igor Vojnovic, "Intergenerational and Intragenerational Equity Requirements for Sustainability”, Environmental Conservation, 22, 3 (1995): 223-228.

40 Tempo.Co, "Rakernas PDIP: Megawati Akan Kembalikan Fungsi MPR Atur GBHN”, https://nasional.tempo.co/read/734681/rakernas-pdipmegawati-akan-kembalikan-fungsi-mpr-atur-gbhn, 10/01/2016, diakses 11/09/2020. Bandingkan: Hernadi Affandi, "Prospek Kewenangan MPR dalam Menetapkan Kembali Ketetapan MPR yang Bersifat Mengatur”, Jurnal Hukum Positum, 1, 1 (2016): 39-50. 
kemiskinan, pengangguran dan kelaparan. ${ }^{41}$

Dari kajian ilmu hukum di Indonesia, satu pendekatan lain dibangun: hukum pertanian. Pertanian di sini harus dibaca lebih dari sekadar ilmu bertani di tegalan (huma) atau sawah atau ladang berpindah. Juga tidak lagi terbatas hanya pada urusan nasib dan keberlanjutan petani gurem atau marhaen atau nelayan tradisional. Pengelolaan sumberdaya alam terbarukan (di sini tidak mencakup urusan pengelolaan pertambangan, minyak dan gas bumi) pada akhirnya adalah urusan budidaya (culture) yang dikembangkan masyarakat-negara dan berkembang dari masa ke masa. Karena itu pula, pertanian harus ditafsirkan dalam arti sangat luas, dalam konteks agri-culture, dan seturut itu pengertian ini akan mencakup perternakan, perikanan, dan semua ikhtiar budaya manusia dalam kegiatan produksi-konsumsi pangan, termasuk agro-industry. ${ }^{42}$ Kegiatan manusia dan masyarakat dalam pengadaan pangan pada akhirnya bukan semata-mata kegiatan ekonomi tapi harus diteropong dari kacamata budaya dan keadaban. Ini pula yang menjadi titik tolak dan cakupan perhatian pengembangan hukum pertanian pada pertanian primer dan tersier (agribisnis dan agroindustri termasuk akuabisnis dan akuaindustri. ${ }^{43}$

Dalam pada itu, titik tolak pengembangan hukum pertanian ini beranjak pula dari pemahaman ketergantungan dan kesatuan manusia pada alam semesta. Ini kiranya sejalan dengan pesan Paus Fransiscus. Ia mengingatkan masyarakat dunia akan perlunya menjaga bumi dan memberikan perhatian pada mereka yang terpinggirkan. ${ }^{44}$ Sebagai perbandingan, perhatian yang sama terhadap keadilan sosial juga ditemukan dalam pemikiran Islam, sebagaimana dikemukakan

41 Jaka Wandira, "Proletarisasi Petani”, Kompas, 22/09/2020: 6.

42 Periksa lema "agriculture” dalam https://pdfs.semanticscholar.org/ae8a/ 9162af7591738e33ed7af6864119fb9036c2.pdf , 11/09/2020; Ben G. Bareja, "What is Agriculture, Definition of Agriculture", https: / www.cropsreview. com/what-is-agriculture.html, edited 26/04/2019, diakses 11/09/2020.

43 Periksa catatan kaki No. 13.

44 http:/ / www.vatican.va/content/francesco/en/encyclicals / documents / papa-francesco_20150524_enciclica-laudato-si.html, "Encyclical Letter Laudato Si' of the Holy Father Francis: On Care for Our Common Home”, diakses $12 / 09 / 2020$. 
Suzana Nabil Saad. ${ }^{45}$ Namun lebih dari itu, pendekatan, termasuk ke dalamnya konsep inter-intra-generational equity, ini sebenarnya sudah tercakup ke dalam prinsip-prinsip hukum lingkungan, hukum lingkungan maupun hukum tata ruang. Konsep pembangunan berkelanjutan berwawasan lingkungan sudah muncul sebagai prinsip hukum dalam Stockholm Declaration, Rio Declaration, Agenda $21^{46}$ dan terakhir Sustainable Development Goals. ${ }^{47}$

45 Suzana Nabil Saad, "Social Justice in Islam”, https: / / islamfaith.com/ socialjustice-in-islam/, diakses 22/09/2020; M. Subhi-Ibrahim, "Sosialisme Religius: Gagasan Pinggiran Nurcholish Madjid, https://ruhullah. wordpress.com / 2008/09/11/ keadilan-sosial-dan-sosialisme-religiusgagasan-pinggiran-nurcholish-madjid/, 11/09/2008, diakses 22/09/2020. Dituliskan, dalam tema keadilan, yang dipaparkan Mutahhari tersebut, Cak Nur lebih banyak menyoroti masalah keadilan sosial (pengertian keadilan kedua). Cak Nur, menemukan bahwa ide keadilan sosial dalam Islam dapat dijumpai dengan mudah dalam al-Quran, terutama dalam ayat-ayat Makkiyah. Secara terang-terangan, al-Quran mengutuk individu dan masyarakat yang anti-keadilan, dengan sistem ekonomi yang tidak produktif dan egois. (QS. Al-Takatsur dan al-Humazah, at- Taubah: 34-35). Bagi Cak Nur, keadilan sosial sejalan dengan egalitarianisme radikal sebagai konsekuensi agama monoteis. Seperti diketahui, dalam agama monoteis, keadilan merupakan misi profetik, tugas suci para Nabi.

46 Untuk uraian singkat tentang sejarah pembentukan-penyusunan Stockholm (1972) dan Rio Declaration (1992), periksa: Günther Handl, "Declaration of the United Nations Conference on the Human Environment (Stockholm Declaration), 1972 and the Rio Declaration on Environment and Development, 1992”, https://legal.un.org/avl/pdf/ha/dunche/dunche_e. pdf, diakses 16/11/2020. Disebutkan: Other policy or legal instruments that emerged from these conferences, such as the Action Plan for the Human Environment at Stockholm and Agenda 21 at Rio, are intimately linked to the two declarations, conceptually as well as politically. However, the declarations, in their own right, represent signal achievements. Adopted twenty years apart, they undeniably represent major milestones in the evolution of international environmental law, bracketing what has been called the "modern era" of international environmental law.

47 United Nations, Transforming Our World: The 2030 Agenda for Sustainable Development, https: / sustainabledevelopment.un.org/content/documents / 21252030\%20Agenda\%20for\%20Sustainable\%20Development\%20web. pdf, diakses 16/11/2020. SDGis ini diterjemahkan pula ke dalam kebijakan nasional, periksa: Kementerian Perencanaan Pembangunan Nasional/ Badan Perencanaan Pembangunan Nasional Republik Indonesia, "Roadmap of SDGs Indonesia: A Highlight”, https://www.unicef.org/indonesia/ media/1626/ file/ Roadmap\%20of\%20SDGs.pdf, diakses 16/11/2020. 
Pentingnya keadilan sosial dan lingkungan ini sebagaimana dicermati dalam ensiklik di atas dan menjadi perhatian pemikirpemikir Islam juga dibincangkan oleh ilmuwan (hukum dan nonhukum) di belahan bumi manapun dan (seharusnya sudah) menjadi perhatian masyarakat dunia. Dari sudut pandang lain disebutkan bahwa perubahan iklim sebagai inconvenient truth $^{48}$ tidak hanya memunculkan bencana dan ancaman bencana alam, tapi juga menunjukkan kemampuan manusia menimbulkan bencana bagi dirinya sendiri dalam skala masif. Munculnya dan berkembangnya bencana kesehatan global akibat perpindahan virus dari hewan ke manusia (flu spanyol, sampar, hiv/aids,ebola, sars-mers, zika dan terakhir Covid-19) nyata menunjukkan bahaya dan risiko eksploitasi sumber daya alam secara berlebih dan tidak terkendali. ${ }^{49}$

Dalam kajian dengan perspektif hukum pertanian, ditelaah kebijakan pembangunan dalam arti luas (pengelolaan sumber daya alam, pertanian, peternakan, dan perikanan), pengaruhnya pada industrialisasi bidang pengelolaan-pengadaan pangan (dalam konteks global chain production) maupun untuk pemenuhan kebutuhan pangan nasional. Terkait dengan itu, seperti telah disinggung, adalah dampak kebijakan-kebijakan negara pada penanggulangan kemiskinan yang juga harus dimaknai secara luas. Ketidakadilan sosial dan ekologi yang terjadi sebagai akibat dan justru dilestarikan kebijakan-kebijakan pemerintah dalam kegiatan pengadaan pangan, dalam konteks ini, harus pula dipahami sebagai faktor penyebab kemiskinan..$^{50}$

48 Al Gore, An Inconvenient Truth: The Crisis of Global Warming (USA: Penguin, 2007).

49 Rob White, Crimes against Nature: Environmental Criminology and Ecological Justice (Cornwall: Willan Publishing, 2008).

50 To be poor is to be hungry, to lack shelter and clothing, to be sick and not cared for, to be illiterate and not schooled. But for poor people, living in poverty is more than this. Poor people are particularly vulnerable to adverse events outside their control. They are often treated badly by the institutions of state and society and excluded from voice and power in those institutions. Baca lebih lanjut: The World Bank, World Development Report, 2000/2001: Attacking Poverty (Newyork: Oxford University Press, 2001). Lihat khususnya: Part I Framework: 1. the nature and Evolution of Poverty, hlm. 15 dan seterusnya. Tersedia di http://documents1.worldbank.org/ curated/en/230351468332946759/pdf/226840WDR00PUB0ng0poverty02 
Dari sudut pandang lain, pendekatan ini pun akan memaksa ilmuwan memikirkan ulang peran dan kedudukan manusia dalam lingkungan. Manusia harus dipandang bukan berada di atas, mengatasi atau sebagai makhluk paling mulia menguasai dan menaklukan lingkungan, namun memandang diri sendiri justru sebagai bagian dari alam semesta, bagian dari ekosistem. ${ }^{51}$

Perspektif yang digunakan melampaui sekadar pendekatan hukum (yuridis normatif atau dogmatis). Ada keniscayaan untuk baik secara diam-diam atau eksplisit memilih jalan transdisiplin atau multi-interdisiplin. Dengan cara ini pula dicoba dikoreksi pendekatan-pendekatan parsial, sektoral, dan fragmentaris dari ilmu hukum yang seringkali kedap terhadap faktor manusia dan terutama rakyat kecil dalam keberagaman suku, ras, agama dan budaya sebagai warga negara seutuhnya. Itu pula sebabnya, imbuhan culture dalam agriculture digunakan sebagai titik tolak.

\section{Relevansi dan Urgensi Hukum Pertanian}

Seberapa pentingkah kajian hukum pertanian di Indonesia. Bukankah kurikulum Fakultas Hukum sudah penuh sesak dengan kajian-kajian khusus; pecahan yang semakin kecil dari pokok-pokok bidang hukum tradisional yang dikenal dengan hukum materiil, seperti pidana, perdata, dagang, hukum tata negara, dan hukum administrasi, serta hukum prosesuil. Pendekatan fragmentaris ini tentu mengancam kemampuan memahami hukum sebagai satu kesatuan sistem yang utuh. ${ }^{52}$ Apa yang dapat diharapkan dari kajian baru ini?

Seperti telah diindikasikan sebelumnya, selama sekian lama hukum negara di Indonesia diposisikan sebagai sarana pembaharuan masyarakat. Arah pembaharuan masyarakat sendiri, sebagaimana dicanangkan pemerintah, ialah menjadi setara dengan negara

00002001.pdf, diakses 12/09/2020.

51 Shiva, "Earth Democracy”. Bandingkan pula dengan gagasan perubahan paradigma dalam hukum lingkungan, dari anthropological centrism ke ecological approach.

52 Adriaan Bedner, "Autonomy of Law in Indonesia", Recht der Werkelijkheid, 37,3 (2016): 10-36. 
industri maju yang bertopang pada inovasi melalui penelitian dan pengembangan (litbang) dalam ilmu pengetahuan dan teknologi (iptek), atau industrial research and development. Untuk mencapai ini selama 30 tahun lebih pembangunan didanai dari keuntungan yang diperoleh negara dari eksploitasi sumber daya alam yang tidak terbarukan (migas, mineral, galian-c) maupun yang kemudian pada prinsipnya terbarukan (kehutanan).

Dalam proses itu, pertanian tradisional di pedesaan yang tersebar di seluruh Indonesia dianggap sebagai hambatan bagi semangat membangun. Begitu juga kehadiran nelayan kecil di pesisir. Perikanan laut harus berkembang menjadi industri besar dan kawasan pesisir dianggap lebih menguntungkan dikembangkan sebagai kawasan parawisata modern yang padat modal. Pola pembangunan yang pada sisi lain memunculkan collateral damage berupa pemiskinan masyarakat pedesaan, hancurnya kegiatan ekonomi rakyat berbasis pertanian dan penangkapan ikan skala kecil dan juga memunculkan kantong-kantong kemiskinan di kota-kota besar di Indonesia.

Di bidang pendidikan tinggi hukum, semangat membangun ini merasuk jauh ke dalam kurikulum. Hukum ekonomi adalah satu contoh dari era 80-90'an, di mana sektor pertanian hanya masuk sebagai satu sub-sektor kecil, dan ini pun tidak menyentuh aspek agrobisnis maupun agroindustri yang di negara-negara maju justru menjadi andalan untuk menjaga kedaulatan, ketahanan, dan keamanan pangan. ${ }^{53}$ Pada masa berikutnya, berkembang hukum bisnis dan sekaligus hukum agraria direduksi menjadi hukum pertanahan dengan fokus pada kegiatan pengadaan tanah bagi pembangunan. Hukum lingkungan dan hukum tata ruang, sebagai hukum sektoral, berkembang menjadi sarana bagi negara untuk

53 Apa yang dikembangkan untuk modernisasi sektor pertanian rakyat disebut dengan green revolution (revolusi hijau) yang sayangnya belum berhasil mengangkat nasib petani kecil. Shankariah Chamala, "Social and Environmental Impacts of Modernization of Agriculture in Developing Countries", Environmental Impact Assessment Review, 10, 1-2 (1990): 219231; Grendi Hendrastomo, "Keterpurukan Sektor Pertanian sebagai Potret Kegagalan Industrialisasi di Indonesia”, Dimensia: Jurnal Kajian Sosiologi, 5, 1 (2011): 71-83. 
terus mendorong pertumbuhan ekonomi yang terpusat di kawasan industri di sekeliling kota-kota besar. Bahkan bidang-bidang hukum lain dikembangkan dalam konteks mengubah dan mengembangkan hukum nasional Indonesia setara dengan sistem hukum negara modern-maju. Hukum masyarakat adat, berkaitan dengan hukum tanah dan aspek lainnya dalam kehidupan keseharian masyarakat adat, hanya dipelajari sepanjang sejalan dengan kepentingan pembangunan.

Pendekatan pembangunan yang sama ternyata masih mewarnai kebijakan pembangunan pasca Orde Baru sampai dengan sekarang. Di atas kertas atau setidaknya dalam Undang-Undang Perlindungan dan Pengelolaan Lingkungan Hidup (UU Nomor 32 Tahun 2009) dan Undang-Undang Tata Ruang (UU Nomor 26 Tahun 2007), Indonesia masih merujuk pada gagasan pembangunan berkelanjutan yang berwawasan lingkungan, yang digagas pada awal 1980'an untuk membenarkan upaya mendorong pertumbuhan ekonomi berlanjut atas dasar eksploitasi sumber daya alam. Pada saat yang sama harus diperhatikan pula fakta bahwa politik dan kebijakan hukum pembangunan Indonesia ${ }^{54}$ dalam praktiknya masih mendahulukan pertumbuhan ekonomi daripada dua sisi lain dari konsep pembangunan berkelanjutan, ialah social justice dan environmental justice. ${ }^{55}$ Dalam kenyataan, pemerintah Indonesia, setidaknya pada rezim Orde $\mathrm{Baru}^{56}$ dan sampai dengan sekarang masih memposisikan diri sebagai

54 Dalam studi hukum di Indonesia, kebijakan hukum berkaitan dengan pembangunan mendapatkan perhatian serius dari Mochtar Kusumaatmadja, yang kemudian melahirkan konsep hukum pembangunan. Konsep hukum pembangunan ini dimaksudkan agar hukum tidak sekadar menjalankan fungsi konservatif yaitu menjaga ketertiban masyarakat, melainkan dapat diberdayakan untuk mengarahkan perubahan dan pembangunan. M. Zulfa Aulia, "Hukum Pembangunan dari Mochtar Kusuma-atmadja: Mengarahkan Pembangunan atau Mengabdi pada Pembangunan?”, Undang: Jurnal Hukum, 1, 2 (2018), hlm. 371-372.

55 Herman E. Daly, "Sustainable Development--Definitions, Principles, Policies", dalam The Future of Sustainability, ed. Marco Keiner (Dordrecht: Springer, 2006). Ia menjelaskan mengapa konsep pertumbuhan ekonomi (pertumbuhan GDP-produktivitas-konsumsi nasional) tidak sejalan dengan konsep pembangunan berkelanjutan.

56 Untuk pembahasan singkat tentang Trilogi Pembangunan, dapat dibaca, 
negara berkembang yang berhak bahkan wajib mengeksploitasi sumber daya alam untuk mengejar ketertinggalan dari negara-negara maju. ${ }^{57}$ Dokumen-dokumen kebijakan dan rencana pembangunan (RPJM-RPJP) kiranya masih dibangun di atas paradigma sama.

Hukum pertanian (agricultural law), yang sejauh ini digagas Koerniatmanto Soetoprawiro, menawarkan suatu upaya untuk membalikkan pemikiran yang sudah mapan. Suatu paradigma berpikir di bidang ilmu hukum yang mencoba menempatkan mereka yang tersingkir dan terpinggirkan, korban anonim dari keberhasilan pembangunan-pertumbuhan ekonomi, sebagai titik tolak. Dengan memberdayakan mereka kembali, melalui pengembangan hukum pertanian, diharapkan laju kehancuran lingkungan hidup dapat dihentikan atau setidak-tidaknya diperlambat dan kita dapat selamat melalui kehancuran ekonomi global ini. Pemberdayaan ini sekaligus membawa konsekuensi bahwa cakupan perhatian dan kajian hukum pertanian tidak terbatas hanya pada aspek perlindungan hukum atas upaya manusia dalam membudayakan dirinya melalui pertanian primer saja, namun melangkah lebih jauh. Persoalan yang dibahas tidak hanya sebatas akses pada lahan maupun pasar, namun juga kedaulatan petani berkenaan dengan bibit dan penjagaanpemeliharaan keanekaragaman hayati. Selain itu, hukum pertanian juga akan mencakup aspek agroindustri dan agrobisnis, termasuk akuabisnis dan akuaindustri modern. Keduanya, industri dan bisnis, dipandang sebagai dua sisi dari keping mata uang yang sama.

antara lain, Dwi Wahyono Hadi dan Gayung Kasuma, "Propaganda Orde Baru 1966-1980”, Verleden, 1, 1 (2012): 40-50; Zainal Arifin Dalimunthe, "Ketergantungan Perekonomian, Trilogi Pembangunan Indonesia dan Pemilu 2014”, Jurnal Ekonomi, 16, 2 (2014): 241-248. Semangat mendahulukan pertumbuhan ekonomi tercermin juga dari ulasan C.F.G. Sunaryati Hartono, Politik Hukum Menuju Pembangunan Ekonomi (Jakarta: Badan Pembinaan Hukum Nasional, 2009).

57 Nicolaas Schrijver, "Self-Determination of Peoples and Sovereignty Over Natural Wealth and Resources", dalam Realizing the Right to Development: Essays in Commemoration of 25 Years of the United Nations Declaration on the Right to Development (New York dan Geneva: United Nations Publication, 2013), tersedia di https://www.ohchr.org/Documents/Publications/ RightDevelopmentInteractive_EN.pdf, diakses 16/11/2020. 
Tentu pendekatan ilmu hukum tidak bekerja instan seperti vaksin. Namun seperti ditunjukan oleh Thomas Kuhn, ${ }^{58}$ pergeseran paradigmatik selalu terjadi dan diperlukan. Perubahan ini bisa terjadi dan diupayakan perlahan secara evolusioner maupun sebagai patahan total dari pemikiran konvensional. Tapi apakah manusia punya waktu untuk menunggu?

\section{E. Kesimpulan}

Artikel ini, dengan mengajukan pilihan kajian hukum pertanian, mencoba menawarkan analisis jawaban mengapa pembangunan yang diselenggarakan justru menjadi salah arah ketika mengabaikan aspek agraria atau agrikultur. Agraria dalam arti luas sekarang ini tereduksi menjadi persoalan pengaturan hak atas tanah dan pengelolaan penguasaan tanah, sementara pertanian dan peternakan dianggap tidak potensial mendorong pembangunan Indonesia. Salah kaprah ini mungkin merupakan warisan pemerintah Hindia Belanda. Kendati begitu setelah lebih dari 75 tahun tentu tidak dapat terus menyalahkan masa lalu. Apa yang pasti adalah modernisasi yang dicanangkan pemerintah Indonesia, terutama sejak Orde Baru sampai dengan sekarang masih terfokus pada pembangunan infrastruktur dan peningkatan produktivitas nasional (GDP). Pertumbuhan ekonomi masih dianggap obat mujarab bagi kemiskinan maupun pembiayaan perlindungan dan pelestarian lingkungan hidup. Dampak dari itu semua adalah kerusakan lingkungan masif dan alineasi manusia dari alam lingkungan.

Apa yang secara ringkas ditunjukkan di atas adalah bagaimana pola pembangunan ini justru bertolak belakang dengan cita pembangunan berkelanjutan yang menekankan pentingnya keadilan sosial dan lingkungan. Di samping itu, apa yang juga mudah terabaikan adalah pentingnya kedaulatan, ketahanan, dan keamanan pangan, tidak saja di tingkat lokal, nasional, tetapi justru global. Salah satu

58 Baca lebih lanjut tentang pemikiran Thomas Kuhn: Alexander Bird, "Thomas Kuhn", dalam The Stanford Encyclopedia of Philosophy (Winter 2018 Edition), ed. Edward N. Zalta, https://plato.stanford.edu/archives/ win2018/entries/thomas-kuhn/, diakses 22/09/2020. 
indikator kemiskinan adalah kelaparan atau sekadar gejala kurang gizi di beberapa tempat Indonesia. Sementara itu, kota-kota besar justru berkelimpahan pangan, pasokan dari industri pertanian modern maupun petani-petani lokal yang kerapkali tidak menikmati hasil-hasil pembangunan. Hal ini menunjukkan adanya sesuatu yang salah, ada ketimpangan dan ketidakadilan struktural (sosial maupun lingkungan). Kajian hukum pertanian dengan fokus pada pengembangan pertanian primer dan tersier merupakan satu ikhtiar untuk turut menyumbang solusi bagi kompleksitas masalah pembangunan dan ketidakadilan sosial-ekonomi yang masih terus dihadapi bangsa ini.

\section{Daftar Pustaka}

Affandi, Hernadi. "Prospek Kewenangan MPR dalam Menetapkan Kembali Ketetapan MPR yang Bersifat Mengatur”. Jurnal Hukum Positum, 1, 1 (2016): 39-50. DOI: 10.35706/positum.v1i1.526.

Antlöv, Hans. Negara dalam Desa: Patronase Kepemimpinan Lokal. Jakarta: Lappera Pustaka Utama, 2013.

Aulia, M. Zulfa. "Hukum Pembangunan dari Mochtar Kusumaatmadja: Mengarahkan Pembangunan atau Mengabdi pada Pembangunan?”. Undang: Jurnal Hukum, 1, 2 (2018): 363-92. DOI: 10.22437 / ujh.1.2.363-392.

Bareja, Ben G. "What is Agriculture, Definition of Agriculture". https: / / www.cropsreview.com/ what-is-agriculture.html, 26/04/2019. Diakses 11/09/2020.

BBC Indonesia. “'Kelaparan' dan Wabah Campak di Papua Menyebar, Korban Jiwa Hampir 100 Orang”, 22/01/2018. https: / www. bbc.com/indonesia/majalah-42758636. Diakses 12/09/2020.

BBC Indonesia. "Covid-19 Papua: 'Rawan Kelaparan' Saat Pandemi, Warga 'Berkebun Massal'”, 22/05/2020. https://www.bbc. com/indonesia/indonesia-52661830. Diakses 12/09/2020.

Bedner, Adriaan. "Autonomy of Law in Indonesia". Recht der Werkelijkheid, 37, 3 (2016): 10-36. DOI: 10.5553/ $\mathrm{RdW} / 138064242016037003002$. 
Berger, Peter. L. Piramida Kurban Manusia: Etika Politik dan Perubahan Sosial. Terjemah oleh A. Rahman Tolleng. Jakarta: LP3ES, 1982.

Bird, Alexander. "Thomas Kuhn”. Dalam The Stanford Encyclopedia of Philosophy (Winter 2018 Edition), diedit oleh Edward N. Zalta. https: / / plato.stanford.edu/archives / win2018/entries/thomaskuhn/. Diakses 22/09/2020.

Byrne, John, Leigh Glover, dan Hugo F. Aloe. "Globalization \& Sustainable Development: A Political Ecology Strategy to Realize Ecological Justice”. Dalam Global Development of Organic Agriculture: Challenges and Prospects, diedit oleh Niels Halberg, Hugo Fjelsted Alroe, Marie Trydeman Knudsen, dan Erik Steen Kristensen, 49-74. Wallingford: CABI Publishing, 2006.

Carson, Rachel. "The Silent Spring". https://ejcj.orfaleacenter. ucsb.edu/wp-content/ uploads / 2017 / 06/ 1962.-Rachel-CarsonSilent-Spring.pdf. Diakses 12/09/2020.

Chamala, Shankariah. "Social and Environmental Impacts of Modernization of Agriculture in Developing Countries". Environmental Impact Assessment Review, 10, 1-2 (1990): 219-231.

Dalimunthe, Zainal Arifin. "Ketergantungan Perekonomian, Trilogi Pembangunan Indonesia dan Pemilu 2014". Jurnal Ekonomi, 16, 2 (2014): 241-248.

Daly, Herman E. "Sustainable Development-Definitions, Principles, Policies". Dalam The Future of Sustainability, diedit oleh Marco Keiner, 39-53. Dordrecht: Springer, 2006. DOI: 10.1007/1-40204908-0_2.

Danusaputro, St. Munadjat. Hukum Lingkungan; Buku I. Jakarta: Binacipta, 1985.

Davis, Mike. Planet of Slums. London \& New York: Verso, 2006.

Detik.Com. "Ini Berbagai Alasan Indonesia Belum Pantas Disebut Negara Maju”. https://finance.detik.com/berita-ekonomibisnis / d-4917366/ini-berbagai-alasan-indonesia-belum-pantasdisebut-negara-maju, 27/02/2020. Diakses 10/09/2020.

FAO. "Trade Reforms andFood Security: Conceptualizing the Linkage, Commodity Policy and Projections Service Commodities and 
Trade Division". Food and Agriculture Organization of The United Nations Rome, 2003. http://www.fao.org/3/y4671e/ y4671e00.htm\#Contents.

Gokkon, Basten. "Everything’s Moving’: Indonesia Seeks Global Pushback on Illegal Fishing". https://news.mongabay. com/2019/01/ everythings-moving-indonesia-seeks-globalpushback-on-illegal-fishing/, 06/01/2019. Diakses 15/10/2020.

Gore, Al. An Inconvenient Truth: The Crisis of Global Warming. USA: Penguin, 2007.

Hadi, Dwi Wahyono dan Gayung Kasuma. "Propaganda Orde Baru 1966-1980”. Verleden, 1, 1 (2012): 40-50.

Handl, Günther. "Declaration of the United Nations Conference on the Human Environment (Stockholm Declaration), 1972 and the Rio Declaration on Environment and Development, 1992”. https://legal.un.org/avl/pdf/ha/dunche/dunche_e. pdf. Diakses 16/11/2020.

Hardjasoemantri, Koesnadi. Hukum Tata Lingkungan. Yogyakarta: Gadjah Mada University Press, 1983.

Hartono, Soenaryati C.F.G. Hukum Ekonomi Pembangunan. Jakarta: BPHN dan Binacipta, 1982.

Hartono, Soenaryati C.F.G. Politik Hukum Menuju Pembangunan Ekonomi. Jakarta: Badan Pembinaan Hukum Nasional, 2009.

Hendrastomo, Grendi. "Keterpurukan Sektor Pertanian sebagai Potret Kegagalan Industrialisasi di Indonesia”. Dimensia: Jurnal Kajian Sosiologi, 5, 1 (2011): 71-83.

http: / / www.vatican.va/ content/francesco/en/encyclicals / documents / papa-francesco_20150524_enciclica-laudato-si. html. "Encyclical Letter Laudato Si' of the Holy Father Francis: On Care for Our Common Home”. Diakses 12/09/2020.

Ilyas, Muhtarom. "Lingkungan Hidup dalam Pandangan Islam". Jurnal Sosial Humaniora, 1, 2 (2008): 154-166.

Kartasasmita, Ginandjar. "Pandemi dan Beban Utang". Kompas, 11/09/2020: 6 .

Kompas.Com. "Berhasil Swasembada Beras, Sejarah Baru pada Kepemimpinan Jokowi-JK. https://money.kompas.com/ 
$\mathrm{read} / 2019 / 10 / 01 / 072600226 /$ berhasil-swasembada-berassejarah-baru-pada-kepemimpinan-jokowi-jk?page $=$ all, 01/10/2019. Diakses 10/09/2020.

La Via Campesina. "Food Sovereignty". https://viacampesina.org/ en/food-sovereignty/, 15/01/2003. Diakses 10/09/2020.

Matanasi, Petrik. "Keculasan Orde Baru Membuat Harga Cengkeh Hancur”. https: / / tirto.id/keculasan-orde-baru-membuatharga-cengkeh-hancur-dhpR, 21/02/2019. Diakses 19/10/2020. Mulyani, Anny, Dwi Kuncoro, Dedi Nursyamsi, dan Fahmuddin Agus. "Analisis Konversi Lahan Sawah: Penggunaan Data Spasial Resolusi Tinggi Memperlihatkan Laju Konversi yang Mengkhawatirkan”. Jurnal Tanah dan Iklim, 40, 2 (2016): 121133.

OECD. "Building Confidence Amid an Uncertain Recovery". OECD Economic Outlook, Interim Report September 2020. http:/ /www. oecd.org/economic-outlook/. Diakses 16/11/2020.

Osborne, David dan Ted Gaebler. Reinventing Government: How the Entrepreneurial Spirit Transforming the Public Sector. Newyork: Addison-Wesley, 1992.

Peters, B. Guy. "Steering, Rowing, Drifting, or Sinking? Changing Patterns of Governance”. Urban Research \& Practice, 4, 1 (2011), 5-12. DOI: 10.1080/17535069.2011.550493.

Purbiyanti, Erni, Muhammad Yazid, dan Indri Januarti. "Konversi Lahan Sawah di Indonesia dan Pengaruhnya terhadap Kebijakan Harga Pembelian Pemerintah (HPP) Gabah/Beras". Jurnal Manajemen \& Agribisnis, 14, 3 (2017): 209-217. DOI: 10.17358/ jma.14.3.209.

Raditya, Iswara N. "Swasembada Beras ala Soeharto: Rapuh dan Cuma Fatamorgana. https://tirto.id/swasembada-beras-alasoeharto-rapuh-dan-cuma-fatamorgana-c2eV, 25/09/2018. Diakses 10/09/2020.

Rangkuti, Siti Sundari. Hukum Lingkungan \& Kebijaksanaan Lingkungan Nasional. Surabaya: Airlangga University Press, edisi keempat, 2020.

Republik Indonesia, Badan Pusat Statistik. Hasil Survei Pertanian 
Antar Sensus (SUTAS) 2018. Jakarta: Badan Pusat Statistik, 2018. https: / www.bps.go.id/publication/2019/10/31/9567dfb39 bd984aa45124b40 / hasil-survei-pertanian-antar-sensus--sutas-2018-seri-a2.html.

Republik Indonesia, Kementerian Perencanaan Pembangunan Nasional/Badan Perencanaan Pembangunan Nasional. "Roadmap of SDGs Indonesia: A Highlight". https://www. unicef.org/indonesia / media/ 1626/ file/ Roadmap\%20of\%20 SDGs.pdf. Diakses 16/11/2020.

Saad, Suzana Nabil. "Social Justice in Islam”. https: / / islamfaith.com/ social-justice-in-islam/. Diakses 22/09/2020.

Schrijver, Nicolaas. "Self-Determination of Peoples and Sovereignty Over Natural Wealth and Resources". Dalam Realizing the Right to Development: Essays in Commemoration of 25 Years of the United Nations Declaration on the Right to Development, 95102. New York dan Geneva: United Nations Publication, 2013. https://www.ohchr.org/Documents/Publications/

RightDevelopmentInteractive_EN.pdf. Diakses 16/11/2020.

Shiva, Vandana. "Earth Democracy: Sustainability, Justice and Peace". Buffalo Environmental Law Journal, 26, 1 (2019): 1-15.

Shiva, Vandana. Earth Democracy: Sustainability, Justice and Peace. London: Zed Books Ltd., 2005.

Soetoprawiro, Koerniatmanto. Hukum Agribisnis dan Agroindustri: Pengaturan dan Perlindungan Hukum atas Proses Agribisnis dan Agroindustri. Bandung, Unpar Press, 2016.

Soetoprawiro, Koerniatmanto. Hukum Akuabisnis dan Akuaindustri. Bandung: Unpar Press, 2020.

Soetoprawiro, Koerniatmanto. Pengantar Hukum Pertanian. Jakarta: Gapperindo, 2013.

Subhi-Ibrahim, M. "Sosialisme Religius: Gagasan Pinggiran Nurcholish Madjid. https:/ / ruhullah.wordpress.com/2008/09/11/ keadilan-sosial-dan-sosialisme-religius-gagasan-pinggirannurcholish-madjid/, 11/09/2008. Diakses 22/09/2020.

Tempo.Co. "Rakernas PDIP: Megawati Akan Kembalikan Fungsi MPR Atur GBHN”. https://nasional.tempo.co/read/734681/ 
rakernas-pdip-megawati-akan-kembalikan-fungsi-mpr-aturgbhn, 10/01/2016. Diakses 11/09/2020.

Tempo.Co. "Siapa Mau Bakar Cengkeh, Laporan Khusus”. https: / / majalah.tempo.co/ read/laporan-khusus/10204/siapa-maubakar-cengkeh, 07/03/1992. Diakses 19/10/2020.

Tempo.Co. "US Removes Indonesia from Developing Countries List”. https: / / en.tempo.co/ read/1311451/ us-removesindonesia-from-developing-countries-list, 24/02/2020. Diakses $10 / 09 / 2020$.

TheWorldBank. WorldDevelopmentReport, 2000/2001:AttackingPoverty.

Newyork: Oxford University Press, 2001. http:// documents1. worldbank.org/curated/en/230351468332946759/pdf/226840 WDR00PUB0ng0poverty0200002001.pdf. Diakses 12/09/2020.

UNICEF. “Laporan Status Anak Dunia 2019: Anak, Pangan, dan Gizi”. https:/ / www.unicef.org/indonesia/id/status-anak-dunia-2019. Diakses 12/09/2020.

United Nations. "Report of the World Commission on Environment and Development: Our Common Future". https:// sustainabledevelopment.un.org/content/ documents / 5987ourcommon-future.pdf. Diakses 12/09/2020.

United Nations. Social Justice in an Open World: The Role of the United Nations. New York: United Nations Publication, 2006. https: / / www.un.org/esa/socdev/documents/ifsd/SocialJustice.pdf.

United Nations. "Transforming Our World: The 2030 Agenda for Sustainable Development". https://sustainabledevelopment. un.org/ content / documents / 21252030\%20Agenda $\% 20$ for $\% 20$ Sustainable\%20Development\%20web.pdf. Diakses 16/11/2020. United Nations Industrial Development Organization. "What are Global Value Chains and Why Do They Matter?”. https:/ / iap. unido.org/articles / what-are-global-value-chains-and-why-dothey-matter. Diakses 12/09/2020.

Vojnovic, Igor. "Intergenerational and Intragenerational Equity Requirements for Sustainability”. Environmental Conservation, 22, 3 (1995): 223-228. DOI:10.1017/S0376892900010626.

Wandira, Jaka. "Proletarisasi Petani”. Kompas, 22/09/2020: 6. 
Tristam Pascal Moeliono \& Koerniatmanto Soetoprawiro

White, Rob. Crimes against Nature: Environmental Criminology and Ecological Justice. Cornwall: Willan Publishing, 2008. 